\title{
ORTHOGRAPHIC OR PHONOLOGICAL?: EXPLORATION OF PREDOMINANT INFORMATION FOR NATIVE JAPANESE READERS IN THE LEXICAL ACCESS OF KANJI WORDS
}

\author{
Rika MIZUNO and Takao MATSUI \\ Department of Psychology, College of Humanities, Chubu University, Japan
}

\begin{abstract}
Native Japanese readers are known to rely heavily on visual codes and far less on phonological codes in letter processing (Mizuno, Matsui, \& Bellezza, 2007). This study aimed to determine whether the lexical access of words written in kanji characters would parallel Japanese letter processing. Two experiments measured native Japanese readers' performance on lexical decision tasks under three nonword conditions: orthographically misleading transposed-letter nonwords, phonologically misleading pseudohomophones, and standard nonwords. The results showed that readers' performance was impaired by transposed-letter nonwords but not by pseudohomophones, suggesting that native Japanese speakers relied heavily on visual information and to a lesser degree on phonological information in the lexical access of kanji words. These characteristics of lexical access in native Japanese readers may be adaptations to the fact that Japanese kanji words have many homophones.
\end{abstract}

Key words: native Japanese readers, lexical access, orthographic information, phonological information, kanji words

Native Japanese readers had been found to rely heavily on visual codes and far less on phonological codes in phonogramic letter processing compared to the other native readers (Matsui \& Mizuno, 2008; Mizuno, Matsui, \& Bellezza, 2007). It was postulated that kanji, the predominant Japanese ideograms, affected the processing of phonograms. Most Japanese kanji characters are polyphones, having two or more pronunciations, and their phonological information might not necessarily be useful to identify them.

We hypothesized that such letter processing feature of native Japanese readers should be true of their word. We will, therefore, explore how visual and phonological information are used in the lexical access of words written in kanji. The reason we chose kanji words was that Japanese words are generally written in kanji characters. Phonogramic hiragana or katakana letters are also used in Japanese, but they are used mostly for function words or foreign words and are thus much less frequent.

Many Japanese kanji words have homophones. Even the number of homophones to

This research was supported by the Grant-in-Aid for Scientific Research (C), 24530927, provided to the authors by the Japanese Society for the Promotion of Science belonging to the Japan Ministry of Education, Culture, Sports, Science \& Technology.

Parts of this article were presented at the 34th annual meeting of the Cognitive Science Society.

Correspondence concerning this article should be addressed to Rika Mizuno, Department of Psychology, College of Humanities, Chubu University, 1200 Matsumoto-cho, Kasugai-shi, Aichi 487-8501, Japan (email: mizunor@isc.chubu.ac.jp). 
a word is sometimes large. Native Japanese readers, therefore, are not necessarily able to reach the target lexicon relying only on their phonological information.

As for the lexical access of such kanji words ${ }^{1}$, various theories have been proposed in terms of the roles of visual and phonological information. In the past, it was generally assumed that visual information of kanji words activates the lexicon without phonological mediation (e.g., Kaiho, 1975; Nomura, 1978, 1979; Saito, 1981). Later, however, Perfetti and Zhang (1995) found that reaction time for subjects' semantic judgments of Chinese homophonic character pairs, which differed only in meaning, was longer than that for ordinary character pairs differing in both meaning and pronunciation. They proposed a universal principle that the phonological information of words should be activated in any language, although the activation level could differ depending on the nature of writing systems; and several studies using Japanese kanji words supported this principle (e.g., Mizuno, 1997). Wydell, Patterson, and Humphreys (1993) and Sakuma, Sasanuma, Tatsumi, and Masaki (1998) found that error rates were greater in semantic decision tasks for Japanese homophonic words than they were for nonhomophonic words only when the homophonic words were orthographically similar to their correct exemplars. Consequently, the authors suggested that visual and phonological processing should occur in parallel during lexical access.

In the above studies suggesting parallel processing of visual and phonological information, the orthographically similar pair shared an identical character in the same position. Therefore, the pair was also phonologically similar. In fact, in Sakuma et al. (1998), the error rate for orthographically similar words in the nonhomophonic condition was lower than that in the homophonic condition and equal to those for orthographically dissimilar words in the two conditions, while the semantic decision times for orthographically similar words in both the homophonic and nonhomophonic condition were longer than those for dissimilar words in the two conditions. Moreover, the phonologically similar words shared the same phonological information with their correct exemplars while the orthographically similar words had only one character in common with their exemplars. Therefore, their orthographical similarity should be relatively low. This problem may be inevitable when words are used as stimuli, because different words having the same visual information but different phonological information do not exist.

We, therefore, determined to manipulate the information of nonwords used in lexical decision tasks, which should increase the freedom of manipulation greatly, supposing as follows. If native Japanese readers would classify stimuli as words or nonwords relying on their orthographic information in lexical decision tasks, orthographically misleading nonwords would impair their task performance. Likewise, if they would classify stimuli relying on their phonological information, phonologically misleading nonwords would

\footnotetext{
${ }^{1}$ Kanji are ideograms having self-contained meanings, and it is quite difficult to differentiate a kanji character from a kanji word. In fact, Kaiho (1975) used single-character kanji words as stimuli to elicit semantic judgments and compared participants' reaction time with that for kana words composed of several letters. He found that the reaction times for kanji words were shorter than those for kana words, and he concluded that phonological processing does not mediate the semantic processing of kanji words. Therefore, the findings described here include the findings of one-character kanji words.
} 
impair their task performance.

Several research examined the effects of misleading nonwords on lexical decision and demonstrated their effects. Shulman and Davidson (1977) found that both orthographically and phonologically legal nonwords (e.g., CHEIR) prolonged lexical decision time unlike illegal nonwords (e.g., CHLQR). Stone and Van Orden (1993) compared the effects of phonologically misleading pseudohomophones (e.g., BEEST), visually misleading orthographically legal nonwords (e.g., DEEST), and orthographically illegal nonwords (e.g., BTESE). They found that orthographically legal nonwords as well as pseudohomophones prolonged lexical decision time. Recently, Lupker and Pexman (2010) compared the performance of lexical decision tasks in the transposed-letter nonword (e.g., AMROR) condition, the pseudohomophone condition, and the standard nonword condition. They found that the means of lexical decision time of words and nonwords were longer and the error rates of nonwords were higher in the transposed-letter nonword and the pseudohomophone conditions than in the standard nonword condition.

All of these research showed that both orthographically misleading nonwords and phonologically misleading nonwords had some effects on the performance of lexical decision tasks. However, these findings were obtained with native English readers. As already mentioned, it is probable that native Japanese readers would rely heavily on orthographic information and to only a small degree on phonological information even in lexical decision, and their performance of lexical decision tasks may not be impaired by phonologically misleading nonwords but only by orthographically misleading nonwords. We therefore decided to compare the performance of native Japanese readers carrying out lexical decision tasks involving various nonword conditions.

\section{EXPERIMENT 1}

Experiment 1 measured lexical decision time and error rates of native Japanese readers in the transposed-letter (TL) nonword condition, the pseudohomophone condition, and the standard nonword condition. We predicted that their lexical decision time of words and nonwords would be delayed and error rates for nonwords would be high only in the TL nonword condition, and not in the pseudohomophone condition and the standard nonword condition.

\section{METHOD}

Participants and Design. Thirty-six undergraduate native Japanese readers (14 women and 22 men) participated in return for course credit. Participants were assigned to all three conditions: the TL nonword, the pseudohomophone, and the standard nonword conditions.

Apparatus. The experiment was conducted on a personal computer (Fujitsu, FMV Esprimo D5350) running an experimental software (Cedrus Co., SuperLab2.0) with a 17-in. liquid crystal monitor (EIZO, FlexScan S1731). Responses were collected by a response box (Cedrus Co., RB-730). A chin support (Takei, T.K.K. 123i with 123j) was placed on the edge of the desk. The distance between participants' eyes and the screen was about $45 \mathrm{~cm}$, and the height of the chin support was adjusted for each participant. 
All the stimuli were two-character and four-mora kanji words. In total, 120 words and 120 nonwords (40 TL nonwords, 40 pseudohomophones, and 40 standard nonwords, see Appendix) were selected/created in the following manner: 240 words of frequencies between 15,000 and 100,000 were selected from the database (Amano \& Kondo, 2003); 40 TL nonwords were made by transposing two kanji characters (e.g., 盟 連, from 連盟), confirming that they had no homophones ${ }^{2}$ and the remaining 200 words were divided into five sets of 40 words each. Three sets were assigned to word sets, another set was used for making pseudohomophones, and another was used for making standard nonwords. Forty pseudohomophones were made by replacing each kanji character with another kanji character with the same phone (e.g., 案低, from 安 定). The 40 standard nonwords were created by exchanging one of the two kanji characters with one of the other words (e.g., 開税), confirming that they were nonwords and had no homophones. The three nonword sets were combined with the three word sets to form six counterbalancing groups.

Japanese letters are typically written from left to right or from top to bottom but sometimes from right to left. The two letters, therefore, were written vertically from top to bottom lest the TL nonwords should be regarded as words. A two-letter stimulus presented on the monitor subtended 3 degrees of visual angles vertically and 1.5 degrees horizontally.

Procedure. Six participants were allocated to each of the six counterbalancing groups. In each group, the orders of three nonword conditions were counterbalanced among the six participants.

Participants were tested individually. Each participant completed eight practice trials with standard nonwords followed by three blocks of 80 experimental trials. The order of the 80 trials was randomized. Participants were instructed to decide as quickly and accurately as possible whether the letter strings were a word or a nonword by pressing the right-most key if they were a word and the left-most key if they were not. In each trial, after a 1,100 ms interval, two asterisks written vertically were presented on the middle of the screen for $550 \mathrm{~ms}$ followed by the stimuli, which remained on the screen for 3,000 $\mathrm{ms}$ or until the participant responded.

\section{RESULTS}

Trials involving latencies greater than $1,500 \mathrm{~ms}(1.2 \%$ of the word trials and $3.2 \%$ of the nonword trials) were removed from the following analyses according to Lupker and Pexman (2010). Two nonwords in the pseudohomophone condition and one nonword in the standard nonword condition also proved to be TL nonwords (see Appendix), and their data were not included in the following analyses.

Word Lexical Decision Time. Means of correct lexical decision time for words in the three nonword conditions are shown in Fig. 1. One-way repeated measures analysis of variance (ANOVA) revealed that the effect of the nonword condition was significant, $F(2$, $70)=27.29, M S E=5,528.08, p<.001$. Multiple comparisons showed that the mean lexical decision time in the TL nonword condition was significantly longer than the pseudohomophone condition and the standard nonword condition, $p \mathrm{~s}<.01, H S D=53.04$, and no difference was found between the pseudohomophone and the standard nonword conditions.

Word Error Rates. Means and standard deviations of error rates for words in the three nonword conditions are shown in Table 1. ANOVA of arcsine transformed error rates revealed that the effect of the nonword condition was not significant, $F(2,70)=1.62$,

\footnotetext{
${ }^{2}$ It is probable that the degree of morphological similarity between actual Japanese words and TL nonwords composed of only two characters differs from that between English words and TL nonwords composed of several letters. However, because the purpose of this study was not to compare data of English words with those of Japanese words, this difference is not problematic.
} 


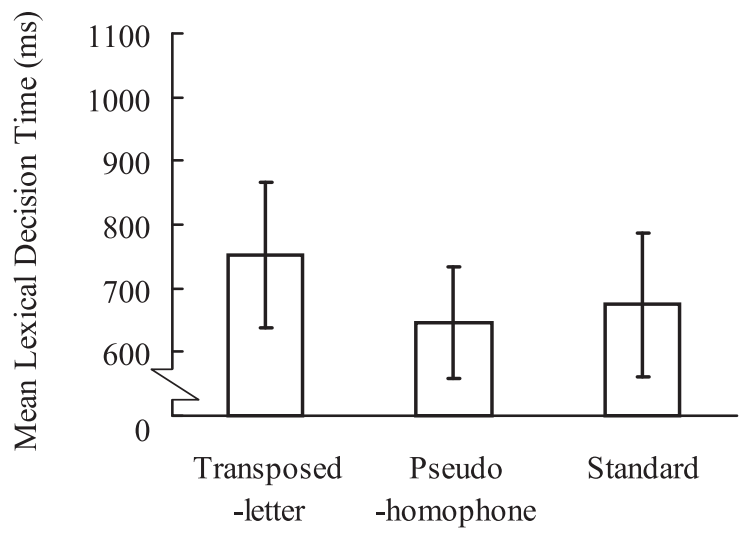

Nonword Condition

Fig. 1. Mean and standard deviation of lexical decision time for words in each nonword condition in Experiment 1.

Table 1. Mean and standard deviation of error rates for words in each nonword condition in Experiment 1

\begin{tabular}{lccc}
\hline & \multicolumn{3}{c}{ Nonword Condition } \\
\cline { 2 - 4 } & Transposed-letter & Pseudo-homophone & Standard \\
\hline Mean & 0.061 & 0.048 & 0.060 \\
$S D$ & 0.043 & 0.039 & 0.037 \\
\hline
\end{tabular}

$M S E=37.97, p=.20$, which was consistent with the result of Lupker and Pexman (2010).

Nonword Lexical Decision Time. Means of correct lexical decision time for nonwords in the three nonword conditions are shown in Fig. 2. ANOVA revealed that the effect of the nonword condition was significant, $F(2,70)=30.80, M S E=7,137.91$, $p<.001$. Multiple comparisons showed that the mean lexical decision time in the TL nonword condition was significantly longer than that in the pseudohomophone condition and the standard nonword condition, $p \mathrm{~s}<.01, H S D=60.27$, and that the time in the pseudohomophone condition was shorter than that in the standard nonword condition, $p<.05, H S D=47.88$.

Nonword Error Rates. Means and standard deviations of error rates for nonwords in the three nonword conditions are shown in Table 2. ANOVA of arcsine transformed error rates showed that the effect of the nonword condition was significant, $F(2,70)=18.00$, $M S E=27.84, p<.001$. Multiple comparisons revealed that the error rate in the TL nonword condition was higher than that in the pseudohomophone condition and the standard nonword condition, $p \mathrm{~s}<.01, H S D=3.76$, and that in the pseudohomophone condition was lower than that in the standard nonword condition, $p<.05, H S D=2.99$. 


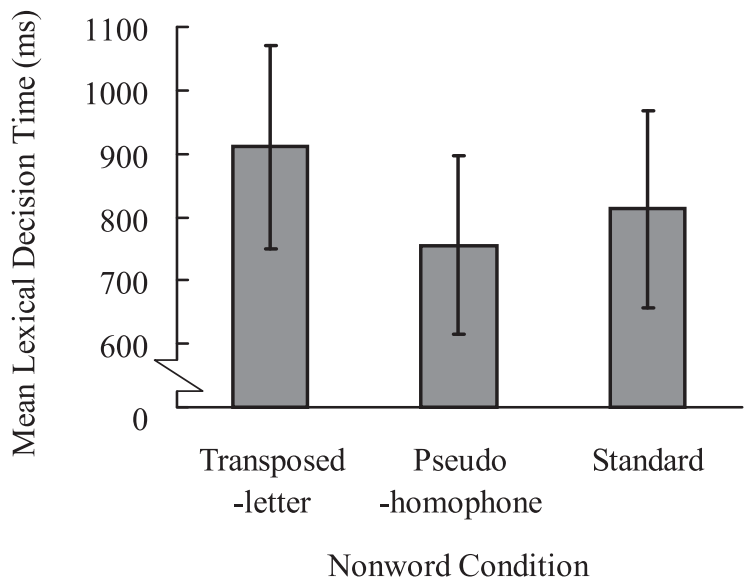

Fig. 2. Mean and standard deviation of lexical decision time for nonwords in each nonword condition in Experiment 1.

Table 2. Mean and standard deviation of error rates for nonwords in each nonword condition in Experiment 1

\begin{tabular}{lccc}
\hline & \multicolumn{3}{c}{ Nonword Condition } \\
\cline { 2 - 4 } & Transposed-letter & Pseudo-homophones & Standard \\
\hline Mean & 0.097 & 0.044 & 0.062 \\
$S D$ & 0.044 & 0.036 & 0.033 \\
\hline
\end{tabular}

\section{DISCUSSION}

The lexical decision time for words in the TL nonword condition was longer than the lexical decision times for words in the pseudohomophone condition and in the standard nonword condition. This result suggests that native Japanese readers rely minimally on phonological information in lexical access. As for nonwords, the results showed that lexical decision time in the TL nonword condition was longer than in the other two conditions, and that error rates in the TL nonword condition were higher than those in the other two conditions. These results indicate that native Japanese readers rely heavily on visual information and do not so much rely on phonological information in lexical access.

However, we did not expect that the lexical decision time in the pseudohomophone condition would be shorter than that in the standard nonword condition, or that the error rate in the pseudohomophone condition would be lower than that in the standard nonword condition. These results were inconsistent with the previously mentioned suggestion itself that native Japanese readers rely minimally on phonological information in lexical access, and we considered it implausible to suppose that the phonological information of pseudohomophones made lexical decision of nonwords easy. 
Table 3. Examples of stroke counts

\begin{tabular}{ccc}
\hline \multicolumn{3}{c}{ Stroke Count } \\
\hline 3 & 8 & 13 \\
\hline 大 & 性 & 新 \\
\hline
\end{tabular}

Therefore, we reexamined the stimuli in the three conditions in detail to find that the mean stroke count (see Table 3) of kanji characters composing pseudohomophones was relatively small. The means of stroke counts (with standard deviations in parentheses) were 9.78 (4.40) for TL nonwords, 8.91 (3.24) for pseudohomophones, and 9.56 (3.73) for standard nonwords. The mean stroke count of pseudohomophones was smaller than the others. The stroke counts of kanji characters reflect their visual complexities. We then considered it possible that this decreased the lexical decision time and error rate of native Japanese readers in the pseudohomophone condition because they would rely heavily on visual information of stimuli.

In Experiment 2, therefore, some of the kanji characters consisting of pseudohomophones and standard nonwords were substituted so as to make the means of stroke counts in the three nonword conditions as even as possible.

\section{EXPERIMENT 2}

\section{METHOD}

Participants and Design. Thirty-six undergraduate native Japanese readers (13 women and 23 men) participated in return for course credit. Participants were assigned to all three conditions: the TL nonword, the pseudohomophone, and the standard nonword conditions.

Stimuli. The 120 words and 40 nonwords in the TL nonword conditions were the same as those used in Experiment 1. Some of the kanji characters in the pseudohomophone condition and the standard nonword condition used in Experiment 1 were substituted with other kanji characters to make the means of stroke counts of kanji characters composing the nonwords in the three conditions as equal as possible (see Appendix). The resultant means (with standard deviations in parentheses) of stroke counts were 9.78 (4.40) in the TL nonword condition, 9.76 (3.52) in the pseudohomophone condition, and 9.78 (3.72) in the standard nonword condition.

Apparatus and Procedure. These were the same as in Experiment 1.

\section{RESULTS}

Trials involving latencies greater than $1,500 \mathrm{~ms}(2.9 \%$ of the word trials and $6.7 \%$ of the nonword trials) were removed from the following analyses as in Experiment 1. One nonword in the pseudohomophone condition and one nonword in the standard nonword condition also proved to be TL nonwords (see Appendix), and their data were not included 


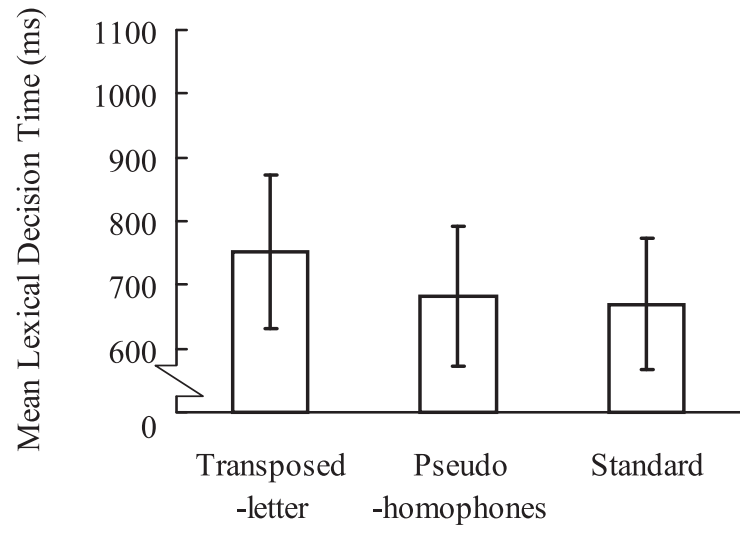

Nonword Condition

Fig. 3. Mean and standard deviation of lexical decision time for words in each nonword condition in Experiment 2.

Table 4. Mean and standard deviation of error rates for words in each nonword condition in Experiment 2

\begin{tabular}{lccc}
\hline & \multicolumn{3}{c}{ Nonword Condition } \\
\cline { 2 - 4 } & Transposed-letter & Pseudo-homophone & Standard \\
\hline Mean & 0.051 & 0.059 & 0.048 \\
$S D$ & 0.044 & 0.049 & 0.038 \\
\hline
\end{tabular}

in the following analyses.

Word Lexical Decision Time. Means of correct lexical decision time for words in the three nonword conditions are shown in Fig. 3. One-way repeated measures ANOVA revealed that the effect of nonword condition was significant, $F(2,70)=12.47$, $M S E=5,572.14, p<.001$. Multiple comparisons showed that the mean lexical decision time in the TL nonword condition was significantly longer than that in the pseudohomophone condition and the standard nonword condition, $p \mathrm{~s}<.01, H S D=53.25$, and no significant difference was found between the pseudohomophone condition and the standard nonword condition.

Word Error Rates. Means and standard deviations of error rates for words in the three nonword conditions are shown in Table 4. ANOVA of arcsine transformed error rates revealed that the effect of the nonword condition was not significant, $F(2,70)=0.32$, $M S E=48.80, p=.73$.

Nonword Lexical Decision Time. Means of correct lexical decision time for nonwords in the three nonword conditions are shown in Fig. 4. ANOVA revealed that the effect of the nonword condition was significant, $F(2,70)=16.52, M S E=9,563.67$, 


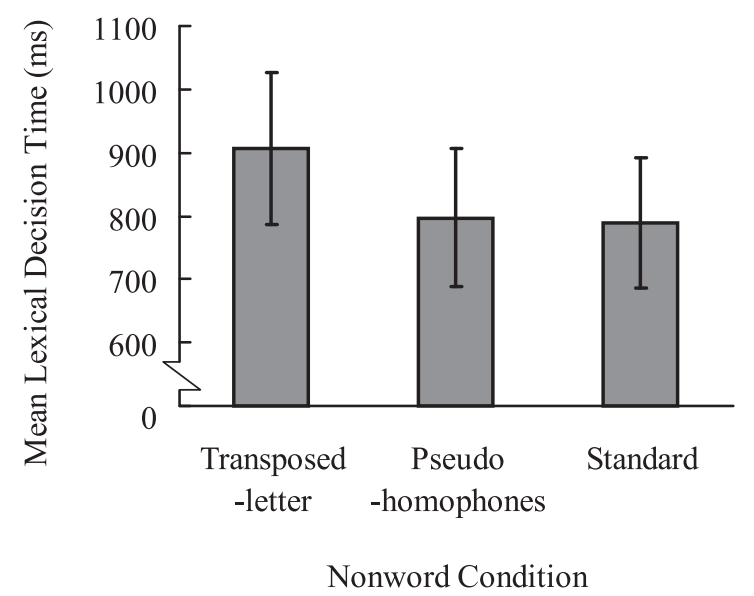

Fig. 4. Mean and standard deviation of lexical decision time for nonwords in each nonword condition in Experiment 2.

Table 5. Mean and standard deviation of error rates for nonwords in each nonword condition in Experiment 2

\begin{tabular}{lccc}
\hline & \multicolumn{3}{c}{ Nonword Condition } \\
\cline { 2 - 4 } & Transposed-letter & Pseudo-homophones & Standard \\
\hline Mean & 0.101 & 0.066 & 0.069 \\
$S D$ & 0.055 & 0.036 & 0.051 \\
\hline
\end{tabular}

$p<.001$. Multiple comparisons showed that the mean lexical decision time in the TL nonword condition was significantly longer than that in the pseudohomophone condition and the standard nonword condition, $p \mathrm{~s}<.01, H S D=69.76$, and there was no significant difference between the pseudohomophone and standard nonword conditions.

Nonword Error Rates. Means and standard deviations of error rates for nonwords in the three nonword conditions are shown in Table 5. ANOVA of arcsine transformed error rates showed that the effect of nonword condition was significant, $F(2,70)=4.87$, $M S E=32.70, p<.01$. Multiple comparisons revealed that the error rate in the TL nonword condition was higher than that in the pseudohomophone condition and the standard nonword condition, $p \mathrm{~s}<.05, H S D=3.24$, and no difference was found between the latter two conditions.

\section{DISCUSSION}

The mean stroke counts of the three nonword conditions were made as equal as possible in Experiment 2. As a result, no difference was found between the 
pseudohomophone and the standard nonword conditions. The lexical decision times of words and nonwords were longer and the error rate of nonwords was higher in the TL nonword condition than those in the other two conditions as predicted.

These results indicate that phonologically misleading nonwords do not impair the lexical decision performance of native Japanese reader, but that visually misleading nonwords do impair it. These support our hypothesis that native Japanese readers would rely to only a small degree on phonological information and heavily on visual information even in lexical access of kanji words just as in processing letters.

\section{GENERAL DiscuSSION}

The results of Experiment 2, in which the means of stroke counts of nonwords in the three conditions were made as even as possible, showed that the means of lexical decision time of words and nonwords were longer and the error rate of words was higher in the TL nonword conditions than those in the pseudohomophone and the standard nonword conditions, and that there was no difference between the latter two conditions. These results indicate that native Japanese readers rely heavily on visual information but minimally on phonological information even in lexical access of words, supporting our hypothesis. In addition, the fact that the number of stroke counts, namely, the visual complexities of nonwords had so much effect on their performance of lexical decision tasks reflects their large dependency on visual information.

These findings, in general terms, served as evidence that characteristics of native words would influence the process of lexical access and, at the same time, gave a methodological warning to all researchers who use lexical decision tasks in terms of making or selecting their stimuli. We then discussed these problems in detail in the following.

\section{Lexical Access Adaptive to the Feature of Native Words}

As described in the introduction, many of Japanese words have homophones. Sometimes, even the number of homophones to a word is many. For example, 申請, 神聖, 新制, 新生, 真性, 心性, 新星, 神性 are all pronounced shinsei. 交涉, 校章, 高尚, 考証, 公称, 厚相, 公証, 口承, 鉱床, 工匠 are all pronounced koushou and more than 40 homophones with this pronunciation are found in a dictionary. Even for first names, 浩二, 幸司, 孝治, 幸二, 康司, 晃司, 功児, 光二, 宏二, 弘治, 孝次 are all pronounced kouji. In fact, it is rather hard for native Japanese speakers to remember people's names by their sounds because sound gives them little information to distinguish people. They need to know kanji characters used for names to identify people, and this should be why Japanese businessmen always present their business cards.

Owing to the large number of homophones, it is sometimes impossible for native Japanese speakers to access the adequate lexicon relying on phonological information of words. We consider that such feature of their native words made them tend to rely less on phonological information and more on visual information than the other native readers in lexical access. 


\section{Methodological Warning for Making Stimuli of Lexical Decision Tasks}

We used to pay little attention to nonwords for lexical decision tasks. However, the results of this study suggest that certain warnings may be helpful to Japanese researchers intending to make use of such tasks.

The results of this study indicated that, for lexical decision tasks using Japanese kanji words and nonwords as stimuli and native Japanese readers as participants, the mean stroke counts of nonwords have to be as equal as possible for all conditions, and that nonwords should never be TL nonwords, but that pseudohomophones should not necessarily be avoided.

\section{Models of Lexical Access}

We finally discuss the process of lexical decision of native Japanese readers in terms of some models of lexical access. According to Shimomura and Goryo (1998), the models of lexical access are roughly divided into two categories: single-route models and dualroute models. Single-route models suppose that phonological information processing always mediates lexical access (e.g., Glushko, 1979). Dual-route models suppose two routes: one is the same with the pathway supposed by single-route models, and another is a direct pathway from visual information to lexicon (e.g., Coltheart, 1978), and some of them also suppose that the information in the two routes interact with each other (e.g., Ferrand \& Grainger, 1994).

The following recent studies support a dual-route model, specially that supposing the interaction between visual and phonological information among them. Grainger, Muneaux, Farioli, and Ziegler (2005) examined the effect of visual and phonological neighborhood density on lexical decision time. They found that lexical decision time was short when both visual neighborhood and phonological neighborhood were dense or sparse because the target lexicon was likely to be the same, namely, because the crosscode consistency was high. They also found that lexical decision time was prolonged when only one of the neighborhoods was dense because the target lexicon was likely to be different, namely, because cross-code consistency was low. They asserted that these results support the dual-route model supposing the interaction between visual and phonological information. Hino, Nakayama, Miyamura, and Kusunose (2011) replicated this study with native Japanese participants using words written in katakana letters as stimuli. They obtained similar results, and argued that the lexical access process for katakana words was also explainable in terms of the same model.

In direct contrast to the findings for katakana by Hino et al. (2011), the results of this study using kanji words indicate that native Japanese readers to a lesser degree rely on phonological information in lexical access. As mentioned in the introduction, katakana words are not as prevalent as kanji words, and it is undeniable that there is an apparent difference between the lexical access processes for katakana and kanji words. We do not, however, assume that their lexical access processes are radically different. Rather, given that the characteristics of kanji characters or words seem to affect the processing of phonogramic letters (Mizuno et al., 2007), we assume that their essential processes are common. We agree with the universal principle proposed by Perfetti and Zhang (1995) - 
the principle was mentioned in the introduction - that the phonological information of words must be activated in any language, with the activation level differing depending on the nature of writing systems. How, then, can the results of English words, those of Japanese katakana words, and those of Japanese kanji words be explained by the same dual-route model?

As already mentioned, Japanese kanji words feature an unparalleled number of homophones. Therefore, native Japanese readers do know that the use of phonological codes of kanji words is not efficient in their lexical access. Accordingly, they choose to rely heavily on visual codes and minimally on phonological codes. The use of pseudohomophones, therefore, does not impair their performance of lexical decision tasks. On the other hand, both English words and katakana words, which are mostly used for foreign words, do not have as many homophones. Native Japanese readers know the situation and do not reduce their reliance on phonological codes. Therefore, the use of pseudohomophones impairs their performance on lexical decision tasks. Thus, the differential results of English words, Japanese katakana words, and Japanese kanji words can be explained by the same dual-route model.

Human information processing must be highly efficient; it is unconceivable that people adhere to inefficient processing. It must also be basically analogous among native readers of different languages. We, therefore, consider that it is most natural and reasonable to suppose that people change flexibly the weights of visual and phonological processing according to the features of their languages, contexts, or situations, realizing the most efficient lexical access.

\section{REFERENCES}

Amano, N., \& Kondo, K. 2003. NTT database series: Lexical properties of Japanese. Vol. 2. CD-ROM Version. Tokyo: Sanseido. (In Japanese)

Coltheart, M. 1978. Lexical access in simple reading tasks. In G. Underwood (Ed.), Strategies of information processing (pp. 151-216). New York: Academic Press.

Ferrand, L., \& Grainger, J. 1994. Effects of orthography are independent of phonology in masked form priming. Quarterly Journal of Experimental Psychology Section A, 47, 365-382.

Glushko, R. J. 1979. The organization and activation of orthographic knowledge in reading aloud. Journal of Experimental Psychology: Human Perception and Performance, 5, 674-691.

Grainger, J., Muneaux, M., Farioli, F., \& Ziegler, J. C. 2005. Effects of phonological and orthographic neighborhood density interact in visual word recognition. Quarterly Journal of Experimental Psychology Section A, 58, 981-998.

Hino, Y., Nakayama, M., Miyamura, S., \& Kusunose, Y. 2011. Orthographic and phonological neighborhood size effects for Japanese katakana words in a lexical decision task. Japanese Journal of Psychology, 81, 569-576. (In Japanese with English abstract)

Kaiho, H. 1975. Semantic information processing of Chinese characters. Journal of Gakugei, Tokushima University. Educational Science, 24, 1-7. (In Japanese with English abstract)

Lupker, S. J., \& Pexman, P. M. 2010. Making things difficult in lexical decision: The impact of pseudohomophones and transposed-letter nonwords on frequency and semantic priming effects. Journal of Experimental Psychology: Learning, Memory, and Cognition, 36, 1267-1289.

Matsui, T., \& Mizuno, R. 2008. How does the letter-encoding process of Chinese readers differ from that of Japanese/English readers? Proceedings of the 25th Annual Meeting of the Japanese Cognitive Science 
Society, 88-89. (In Japanese)

Mizuno, R. 1997. A test of a hypothesis of automatic phonological processing of Kanji words. Japanese Journal of Psychology, 68, 1-8. (In Japanese with English abstract)

Mizuno, R., Matsui, T., \& Bellezza, F. S. 2007. Difference between native English and native Japanese readers in the use of visual and phonological codes in processing phonograms. Japanese Journal of Cognitive Psychology, 5, 1-10. (In Japanese with English abstract)

Nomura, Y. 1978. The information processing of Chinese characters (Kanji): Chinese reading, Japanese reading and the attachment of meaning. Japanese Journal of Psychology, 49, 190-197. (In Japanese with English abstract)

Nomura, Y. 1979. Information processing of Chinese characters (kanji): Retrieval processes in Chinese-style reading (on) and Japanese-style reading (kun). Japanese Journal of Psychology, 50, 101-105. (In Japanese with English abstract)

Perfetti, C. A., \& Zhang, S. 1995. Very early phonological activation in Chinese reading. Journal of Experimental Psychology: Learning, Memory, and Cognition, 21, 24-33.

Saito, H. 1981. Use of graphemic and phonemic encoding in reading Kanji and Kana. Japanese Journal of Psychology, 52, 266-273. (In Japanese with English abstract)

Sakuma, N., Sasanuma, S., Tatsumi, I. F., \& Masaki, S. 1998. Orthography and phonology in reading Japanese kanji words: Evidence from the semantic decision task with homophones. Memory \& Cognition, 26, 75-87.

Shimomura, M., \& Goryo, K. 1998. Word recognition and the concept of mental lexicon. In N. Osaka (Ed.), Reading: Information processing in brain and mind. Tokyo: Asakura Publishing. (In Japanese)

Shulman, H. G., \& Davidson, T. C. B. 1977. Control properties of semantic coding in a lexical decision task. Journal of Verbal Learning and Verbal Behavior, 16, 91-98.

Stone, G. O., \& Van Orden, G. C. 1993. Strategic control of processing in word recognition. Journal of Experimental Psychology: Human Perception and Performance, 19, 744-774.

Wydell, T. N., Patterson, K. E., \& Humphreys, G. W. 1993. Phonologically mediated access to meaning for Kanji: Is a rows still a rose in Japanese Kanji? Journal of Experimental Psychology: Learning, Memory, and Cognition, 19, 491-514.

(Manuscript received 5 September, 2012; Revision accepted 26 June, 2013) 
Appendix

Nonwords for Experiment 1 and Experiment 2

\begin{tabular}{|c|c|c|c|c|c|c|c|c|c|c|c|}
\hline \multicolumn{12}{|c|}{ Experiment 1} \\
\hline \multicolumn{4}{|c|}{ Transposed-Letter Nonwords } & \multicolumn{4}{|c|}{ Pseudohomophones } & \multicolumn{4}{|c|}{ Standard Nonwords } \\
\hline 盟連 & 察検 & 続継 & 発反 & 案低 & 件公 & 柵元 & 段対 & 開税 & 方閣 & 撃政 & 営開 \\
\hline 員役 & 式株 & 練訓 & 復回 & 英増 & 限財 & 産聖 & 短棟 & 展合 & 内体 & 動読 & 応策 \\
\hline 影撮 & 式公 & 大最 & 分半 & 解害 & 研塔 & 芯甲 & 塔欠 & 応会 & 合進 & 国進 & 員結 \\
\hline 学大 & 識認 & 択採 & 束約 & 階核 & 項円 & 信分 & 党千 & 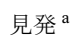 & 額民 & 総民 & 造攻 \\
\hline 割分 & 者若 & 断判 & 民難 & 会再 $^{a}$ & 剛刑 & 製件 & 文席 & 金反 & 戦税 & 登金 & 運格 \\
\hline 還返 & 人犯 & 的目 & 門専 & 回前 ${ }^{a}$ & 公層 & 製現 & 変再 & 律生 & 間法 & 用全 & 談神 \\
\hline 型大 & 人法 & 道鉄 & 躍活 & 会砲 & 高態 & 聖姪 & 方動 & 年促 & 決大 & 父推 & 統対 \\
\hline 迎歓 & 数定 & 督監 & 用適 & 各第 & 号動 & 線宅 & 洋院 & 産演 & 連験 & 論親 & 役経 \\
\hline 策対 & 籍国 & 任責 & 絡連 & 感計 & 才回 & 隊公 & 洋制 & 反法 & 年争 & 物陣 & 割戒 \\
\hline 察警 & 族民 & 問訪 & 立確 & 間線 & 在姓 & 耐律 & 欲聖 & 解末 & 推録 & 説験 & 友抵 \\
\hline \multicolumn{12}{|c|}{ Experiment 2} \\
\hline \multicolumn{4}{|c|}{ Transposed-Letter Nonwords } & \multicolumn{4}{|c|}{ Pseudohomophones } & \multicolumn{4}{|c|}{ Standard Nonwords } \\
\hline & & & & & 県校 & 策元 & 談対 & 快税 & & & \\
\hline & & & & & 源財 & 産性 & 単島 & & & & \\
\hline & & & & & 権党 & 新講 & 頭決 & 欧会 & 号進 & 国新 & \\
\hline & & & & & 高円 & & 党線 & & & & \\
\hline & & & & 界歳 & 号警 & 性県 & & & & 登均 & \\
\hline & & & & & 校総 & & & & & & \\
\hline & & & & & 高対 & 製名 & & & 決題 & 卓推 & \\
\hline & & & & & & & 用院 & & & & \\
\hline & & & & & 最会 & 態公 & 用制 & 判包 & 念争 & & \\
\hline & & & & 間選 & 在勢 & 態率 & 欲正 & & & & \\
\hline
\end{tabular}

Note. Nonwords written in block are those differed between Experiment 1 and Experiment 2.

a These nonwords were also TL nonowords and their data were not included in the analyses. 